\title{
Development of an HPLC method for the radiochemical
}

\section{purity evaluation of $\left[{ }^{18} \mathrm{~F}\right]$ fluoroestradiol}

\author{
A. C. A. Bispo ${ }^{\text {a }}$ L. T. C. Nascimento ${ }^{\text {a }}$ F. M. Costa ${ }^{\text {a }}$ J. B. Silva $a^{\text {a }}$ M. Mamede \\ ${ }^{a}$ Unidade de Pesquisa e Produção de Radiofármacos/Centro de Desenvolvimento da Tecnologia Nuclear \\ (CDTN/CNEN - MG), 31270-901, Belo Horizonte, Minas Gerais, Brazil \\ ${ }^{b}$ Departamento de Anatomia e Imagem/Faculdade de Medicina/Universidade Federal de Minas Gerais (UFMG), \\ 30130-100, Belo Horizonte, Minas Gerais, Brazil \\ anacarollbispo@gmail.com
}

\begin{abstract}
${ }^{18}$ F-Fluoroestradiol $\left(\left[{ }^{18} \mathrm{~F}\right] \mathrm{FES}\right)$, an estrogen analog, is a radiopharmaceutical used in Positron Emission Tomography (PET) that allows evaluating the tumor cell receptor profile and the best therapy strategy, the staging, the prognosis and the response to therapy in several breast cancer cases. As there is not any pharmacopoeia's monograph of $\left[{ }^{18} \mathrm{~F}\right] \mathrm{FES}$ to standardize its quality control criteria, this work presents a new HPLC's method to perform the $\left[{ }^{18}\right.$ F]FES radiochemical purity. A liquid chromatograph was used with radioactivity and ultraviolet detectors. Three concentrations of fluoroestradiol standard solution were used along the test. Their retention time was compared to its relative radiolabelled analogue to confirm its identity. Several mobile phases with acetonitrile and two mobile phase flows were tested to optimize the runs. Peaks symmetry, retention time, theoretical plates and resolution were analyzed to choose the best conditions. The mean retention time of both standard Fluoroestradiol and $\left[{ }^{18} \mathrm{~F}\right] \mathrm{FES}$ solutions were the same, demonstrating that $\left[{ }^{18} \mathrm{~F}\right] \mathrm{FES}$ formulation did not interfere with $\left[{ }^{18} \mathrm{~F}\right] \mathrm{FES}$ analysis. The best conditions were $1.2 \mathrm{~mL} / \mathrm{min}$ and isocratic $40 \% \mathrm{~V} / \mathrm{V}$ acetonitrile in water, which gave $\left[{ }^{18} \mathrm{~F}\right] \mathrm{FES}$ peak resolution greater than 6 and symmetry factor of 1. Thus, the developed method is ready to be validated and implemented in $\left[{ }^{18} \mathrm{~F}\right] \mathrm{FES}$ quality control routine in CDTN/Brazil.
\end{abstract}

Keywords: ${ }^{18}$ F-Fluoroestradiol, HPLC, Radiochemical Purity. 


\section{INTRODUCTION}

Breast cancer is the most prevalent type of cancer in women and the principal cause of death by cancer worldwide [1]. If diagnosed and treated early, breast cancer has a good prognosis. However, mortality rates from this cancer remain high in Brazil, most likely because this disease is still diagnosed in advanced stages [2]. An early diagnosis allows the treatment to be started more quickly, which has an important impact in reducing the mortality and the morbidity of the disease [3].

Positron Emission Tomography (PET) is an exam that allows the molecular evaluation of physiological, biochemical and pharmacological events that occur in a cell [4]. It can be used to identify the biological and functional changes that occur in a tumor cell, generating an early diagnosis of cancer in a noninvasive way. Currently, $18 \mathrm{~F}$-fludesoxyglucose $\left(\left[{ }^{18} \mathrm{~F}\right] \mathrm{FDG}\right)$ is the most widely used radiopharmaceutical for breast cancer diagnosis, and its use is based on the affinity for cells with increased glycolytic metabolism [5]. However, it is known that it may not be the ideal radiotracer for the image of this type of cancer [6]. Infection sites may generate false positive results, whereas malignant tumors with low metabolic activity may result in false negative results [7]. Thus, to optimize the detection of neoplastic cells, it is necessary to develop new radiopharmaceuticals directed to other tumor markers.

Breast cancer is a pathology that presents several subtypes, which are differentiated by the expression profile of hormone receptors. Approximately two-thirds of breast cancers have estrogendependent and/or progesterone-dependent growth [8]. Thus, the development of a radiopharmaceutical that has affinity for these receptors is desirable. Once the $\left[{ }^{18} \mathrm{~F}\right]$ fluoroestradiol $\left(\left[{ }^{18} \mathrm{~F}\right] \mathrm{FES}\right)$, an estrogen analogue, has been considered a promising radiotracer for breast cancer cases, its use has been proposed in this study [9].

$\left[{ }^{18} \mathrm{~F}\right]$ Fluoroestradiol has similar characteristics to estradiol, both in its molecular structure and in its transport in the organism, providing high affinity for nuclear estrogen receptors [9]. Its use in the clinic allows the evaluation of the receptor profile of tumor cells, an important factor for determining the best therapy to be used, with a potential value in the staging of the disease, in the prognosis and in the response to the therapy used [5,9]. 
$\left[{ }^{18} \mathrm{~F}\right] \mathrm{FES}$ does not have an official monograph in any Pharmacopeia. Thus, all quality control tests must be developed and validated by its producers. One of these tests is the radiochemical purity, which measures the percentage of the radiopharmaceuticals's activity in the entire formulation's activity. This analysis is also used to determine the efficiency of the labeling step of the molecule with ${ }^{18} \mathrm{~F}$ [10]. Therefore, the objective is validate a new methodology for the analysis of the radiochemical purity of $\left[{ }^{18} \mathrm{~F}\right]$ fluoroestradiol.

\section{MATERIALS AND METHODS}

\subsection{Materials}

Fluoroestradiol and precursor (MMSE) standards were purchased from ABX (Germany). Acetonitrile HPLC grade was purchased from Merck (Germany). Water was purified in a Milli-Q Plus system (Millipore, USA). The cassette, reagents kit and software sequence used for $\left[{ }^{18} \mathrm{~F}\right] \mathrm{FES}$ synthesis were purchased from $\mathrm{ABX}$ (Germany). ${ }^{18} \mathrm{O}$ enriched water used to ${ }^{18} \mathrm{~F}$ production was purchased from Center of Molecular Researches Isotopes (Russia)

\subsection{Instrumentation}

A General Eletric TracerLab MXFDG module (UK) was used for the $\left[{ }^{18} \mathrm{~F}\right] \mathrm{FES}$ synthesis. ${ }^{18} \mathrm{~F}$ was produced in a 16,5 MeV GE Cyclotron PETrace (UK).

An Agilent Technologies HPLC (High performance liquid chromatography) system, model 1200 (USA), was used for method development. The HPLC system was equipped with a manual injector, $20 \mu \mathrm{L}$ loop, radiation (Raytest, Germany) and ultraviolet (Agilent Tecnologies, at $280 \mathrm{~nm}$ ) detectors. Data acquisition, analysis, and reporting were performed using the equipment software. HPLC analysis was conducted using a Luna C18 (2) column (Phemonenex, USA), with $5 \mu$ m particle size, $4.6 \mathrm{~mm}$ internal diameter and $250 \mathrm{~mm}$ length.

\subsection{Synthesis of $\left[{ }^{18}\right.$ F]Fluoroestradiol}

$\left[{ }^{18} \mathrm{~F}\right] \mathrm{FES}$ synthesis was based on the methodology described by Knott et al [11], but some modifications were made aiming to improve yield. $\left[{ }^{18} \mathrm{~F}\right]$ Fluoride was produced via the ${ }^{18} \mathrm{O}(\mathrm{p}, \mathrm{n}){ }^{18} \mathrm{~F}$ 
nuclear reaction. Both fluorination and hydrolyses steps were performed at $110{ }^{\circ} \mathrm{C}$. $\left[{ }^{18} \mathrm{~F}\right] \mathrm{FES}$ is obtained in a $10 \% \mathrm{w} / \mathrm{v}$ ethanolic saline solution sterilized through a $0.22 \mu \mathrm{m}$ membrane filter. Total synthesis time was about $75 \mathrm{~min}$.

\subsection{Preparation of Standard and Sample Solutions}

A stock solution of $100 \mu \mathrm{g} / \mathrm{mL}$ of fluoroestradiol (reference standard for $16 \alpha-\left[{ }^{18} \mathrm{~F}\right]$ Fluoroestradiol, ABX, Germany) was prepared in acetonitrile (Merck, Germany) and subsequent dilutions were performed to obtain standard solutions of 1.0, 5.0 and $10.0 \mu \mathrm{g} / \mathrm{mL}$. Similarly, 3 standard solutions, with same concentrations, were obtained for MMSE (precursor for $16 \alpha-\left[{ }^{18} \mathrm{~F}\right]$ Fluoroestradiol, ABX, Germany), similarly diluted in acetonitrile. The standards and samples had previously been filtered through a $0.22 \mu \mathrm{m}$ pore size filter (Millipore, USA) prior to injection.

The $\left[{ }^{18}\right.$ F]FES samples were obtained directly from the final solution produced, without dilution.

\subsection{Chromatographic Conditions}

Chromatographic analyses were performed with a sample injection volume of $20 \mu \mathrm{L}$ and the detection wavelength in $280 \mathrm{~nm}$. The mobile phase consisted of isocratics mixtures acetonitrile:water, in the proportions 40:60 (v/v), 50:50 (v/v), 60:40 (v/v), 70:30 (v/v) or 80:20 (v/v). Two gradients conditions were also tested: one ranging from $70 \%(\mathrm{v} / \mathrm{v})$ to $90 \%(\mathrm{v} / \mathrm{v})$ and another ranging from $80 \%(\mathrm{v} / \mathrm{v})$ to $90 \%(\mathrm{v} / \mathrm{v})$ of acetonitrile. Flow rates of 1.0 and $1.2 \mathrm{~mL} / \mathrm{min}$ were tested, aiming to improve the runs. The method run time was $30 \mathrm{~min}$, and all experiments were performed at $20{ }^{\circ} \mathrm{C}$. Peaks symmetry, retention time $\left(t_{R}\right)$, theoretical plates $(N)$ and resolution $\left(R_{s}\right)$ were obtained through the chromatograph software and analyzed to choose the best conditions. Symmetry was calculated by the formula $\mathrm{A}_{\mathrm{s}}=\mathrm{w}_{0.05} / 2 \mathrm{~d}$, where $\mathrm{w}_{0.05}$ is the width of the peak at $5 \%$ height and $d$ is the distance from the peak maximum to the leading edge of the peak, the distance being measured at a point $5 \%$ of the peak height from the baseline $[12,13]$; Theoretical plates was calculate by $\mathrm{N}=5.54\left(\mathrm{t}_{\mathrm{R}} / \mathrm{w}_{1 / 2}\right)^{2}$, where $\mathrm{w}_{1 / 2}$ is the peak width at half height $[12,13]$; and resolution by the formula $R_{s}=(\sqrt{ } N) / 4 \times(\alpha-1) / \alpha \times k /(k+1)$, where $\alpha$ is the separation factor and $\mathrm{k}$ is the retention factor [12]. 


\section{RESULTS AND DISCUSSION}

During the analyses, an instable baseline, peaks with shoulders and an irregular shape of the $\left[{ }^{18} \mathrm{~F}\right] \mathrm{FES}$ peak were observed when the acetonitrile proportion was higher than the water. Increasing the water proportion in the mobile phase, the peaks in the chromatogram have become each more regular and with higher resolution. Acetonitrile:water proportion of 40:60 (v/v) gave peaks properly spaced in chromatogram with satisfactory values of symmetry, theoretical plates, resolution (Table 1) and a stable baseline. This mobile phase was the best $\left[{ }^{18} \mathrm{~F}\right] \mathrm{FES}$ analysis condition, which is in agreement with previous work [14,15].

Table 1: Chromatographic parameters of $\left[{ }^{18} \mathrm{~F}\right] \mathrm{FES}$ peak, when analyzed with the mobile phase acetonitrile:water 40:60 (v/v) and $1.2 \mathrm{~mL} / \mathrm{min}$.

\begin{tabular}{lccc}
\hline Parameters & UV detector $^{\mathbf{a}}$ & Radiation detector $^{\mathbf{a}}$ & Reference $^{[12]}$ \\
\hline Resolution & 6.35 & 1.15 & $>1^{[12}$ \\
Symmetry & 0.941 & 1.010 & As close as possible to $1.0^{[12,16]}$ \\
Theoretical plates & 15186 & 13285 & Highest possible value $^{[12,13,16]}$ \\
Retention time & 13.7 & 13.7 & - \\
\hline
\end{tabular}

a. Average results $(n=3)$.

In order to optimize the analysis time of $\left[{ }^{18} \mathrm{~F}\right] \mathrm{FES}$, the flow from the mobile phase was varied from $1.0 \mathrm{~mL} / \mathrm{min}$ to $1.2 \mathrm{~mL} / \mathrm{min}$. The flow rate of $1.2 \mathrm{~mL} / \mathrm{min}$ caused a shift in the peaks, leading to a decrement in the retention time of all peaks. Therefore, the total run time could be reduced from 30 to 18 minutes. Under these conditions, the $\left[{ }^{18} \mathrm{~F}\right] \mathrm{FES}$ retention time was $13.7 \mathrm{~min}$ (Figure 1 ) and the mean retention time of both standard fluoroestradiol and $\left[{ }^{18} \mathrm{~F}\right] \mathrm{FES}$ solutions were the same (Table 1), demonstrating that $\left[{ }^{18} \mathrm{~F}\right] \mathrm{FES}$ formulation, did not interfere with HPLC analysis.

It was also observed that there is no precursor's peak in the $\left[{ }^{18} \mathrm{~F}\right] \mathrm{FES}$ formulation chromatogram, suggesting that is fully consumed or degraded. This fact is reported in a previous work [17].

Some impurities were observed in the final products chromatograms, although not identified yet. However, the sum of these peaks areas did not exceed the impurities limit of $10 \%$ presented in the 
American Pharmacopoeia, in $\left[{ }^{18} \mathrm{~F}\right] \mathrm{FDG}$ monograph [13], demonstrating that the observed impurities do not interfere with the final product quality.

Figure 1: HPLC chromatogram of $\left[{ }^{18}\right.$ F]FES. Conditions: mobile phase acetonitrile:water 40:60 $(v / v)$ at $1.2 \mathrm{~mL} / \mathrm{min}$; stationary phase C18(2) column with 5 um particle size, $4.6 \times 250 \mathrm{~mm}$; radioactivity (lower chromatogram) and UV (upper chromatogram at $280 \mathrm{~nm}$ ) detectors. Injected activity: 1,3 mCi. Radiochemistry purity: $94.41 \%$.

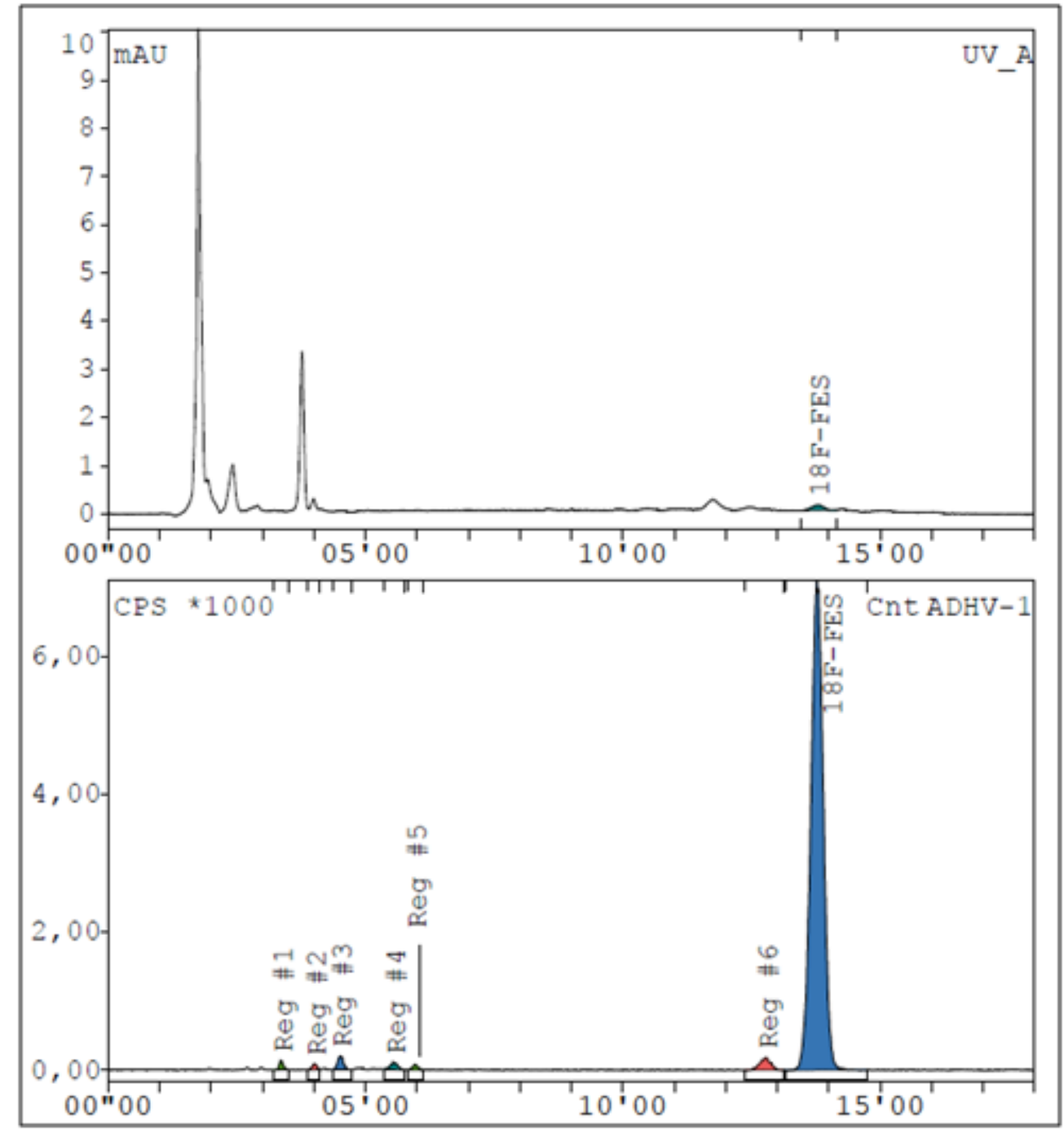

\section{CONCLUSION}


The best condition to the analysis of $\left[{ }^{18} \mathrm{~F}\right] \mathrm{FES}$ radiochemistry purity was $1.2 \mathrm{~mL} / \mathrm{min}$ and isocratic $40 \% \mathrm{~V} / \mathrm{V}$ acetonitrile in water, which gave $\left[{ }^{18} \mathrm{~F}\right] \mathrm{FES}$ peak resolution greater than 1 and symmetry factor of 1 . This method proved to quantify $\left[{ }^{18} \mathrm{~F}\right] \mathrm{FES}$ independently of formulation components, as well as prove that precursor is not detected in the final product. In addition, this methodology proved to be effective, being able to identify degradations and formulation changes when present.

Thus, the developed method is ready to be validated and implemented in $\left[{ }^{18} \mathrm{~F}\right] \mathrm{FES}$ quality control routine in CDTN/Brazil.

\section{ACKNOWLEDGMENT}

The authors wish to thank the whole group of UPPR/CDTN for technical support on production and quality control of $\left[{ }^{18} \mathrm{~F}\right] \mathrm{FES}$. This research was supported by Centro de Desenvolvimento da Tecnologia Nuclear (CDTN/CNEN-MG), Fundação de Amparo à Pesquisa (FAPEMIG), INCT de Medicina Molecular, Conselho Nacional de Desenvolvimento Científico e Tecnológico (CNPq) and Comissão de Aperfeiçoamento de Pessoal do Nível Superior (CAPES - scholarship).

\section{REFERENCES}

1. MINISTÉRIO DA SAÚDE. INCA - Instituto Nacional do Câncer José Alencar Gomes da Silva. Estimativa 2016: Incidência de Câncer no Brasil. Rio de Janeiro: INCA, p. 32-34. 2015. Available at: <http://www.inca.gov.br/estimativa/2016/estimativa-2016-v11.pdf>. Last accessed: 23 Jun. 2016.

2. MINISTÉRIO DA SAÚDE. INCA - Instituto Nacional do Câncer José Alencar Gomes da Silva. Estimativa 2014: Incidência de Câncer no Brasil. Rio de Janeiro: INCA, p. 34-35. 2014. Available at: <http://www.saude.sp.gov.br/resources/ses/perfil/gestor/homepage/outros-destaques/ estimativa-de-incidencia-de-cancer-2014/estimativa_cancer_24042014.pdf>. Last accessed: 10 Dec. 2014.

3. RODRIGUES, K. E.; CAMARGO, B. Diagnóstico precoce do câncer infantil: responsabilidade de todos. Rev Assoc Med Bras, v. 49, p. 29-34, 2003. 
4. JACOBSON, O.; CHEN, X. PET Designated Fluoride-18 Production and Chemistry. Curr Top Med Chem, v. 10, p. 1048-1059, 2010.

5. FlanagAn, F. L.; DEHDAShti, F.; SIEGEL, B. A. PET in Breast Cancer. Semin Nucl Med, v. 28, p. 290-302, 1998.

6. SURTI, S. Radionuclide Methods and Instrumentation for Breast Cancer Detection and Diagnosis. Semin Nucl Med, v. 43, p. 271-280, 2013.

7. CHAN, J. M.; LEE, H. J.; GOO, J. M.; LEE, H. Y.; LEE, J. J.; CHUNG, J. K.; IM, J. G. False Positive and False Negative FDG-PET Scans in Various Thoracic Diseases. Korean J Radiol, v. 7, p. 57-69, 2006.

8. LINDEN, H. M. L.; DEHDASHTI, F. Novel Methods and Tracers for Breast Cancer Imaging. Semin Nucl Med, v. 43, p. 324-329, 2013.

9. SUNDARARAJAN, L.; LINDEN, H. M.; LINK, J. M.; KROHN, K. A.; MANKOFF, D. A. ${ }^{18}$ F-Fluoroestradiol. Semin Nucl Med, v. 37, p. 470-476, 2007.

10. ANVISA - Agência Nacional de Vigilância Sanitária. Farmacopeia Brasileira. $5^{\text {th }}$ ed. Brasília, Brazil: Anvisa, v. 1, p. 374. 2010. Available at: <http://www.anvisa.gov.br/hotsite/cd_ farmacopeia/pdf/volume2.pdf>. Last accessed: 13 Sep. 2017.

11. KNOTT, K. E.; GRÄTZ, D.; HÜBNER, S.; JÜTTLER, S.; ZANKL, C.; MÜLlER, M. Simplified and automatic one-pot synthesis of $16 \alpha-\left[{ }^{18} \mathrm{~F}\right]$ fluoroestradiol without high-performance liquid chromatography purification. J Label Compd Radiopharm, v. 54, p. 749-753, 2011.

\section{AGILENT TECHNOLOGIES. The LC Handbook: Guide to LC Columns and Method}

Development. USA: Agilent Technologies, 2016. Available at: <https://www.agilent.com/cs/ library/primers/Public/LC-Handbook-Complete-2.pdf>. Last accessed: 13 Sep. 2017. 
13. UNITED STATES PHAMACOPEIAL CONVENTION. USP/NF 2016 - United States Phamacopeia/National Formulary. $39^{\text {th }}$ ed., v. 1. Rockville, USA: United States Pharmacopeia, 2016.

14. KUMAR, P.; MERCER, J.; DOERKSON, C.; TONKIN, K.; MCEWAN, A. J. B. Clinical production, stability studies and PET imaging with $16-\alpha-\left[{ }^{18} \mathrm{~F}\right]$ fluoroestradiol $\left(\left[{ }^{18} \mathrm{~F}\right] \mathrm{FES}\right)$ in ER positive breast cancer patients. J Pharm Pharm Sci, v. 10, p. 256s-265s, 2007.

15. MORI, T.; KASAMATSU, S.; MOSDZIANOWSKI, C.; WELCH, M. J.; YONEKURA, Y.; FUJIBAYASHI, Y. Automatic synthesis of $16 \alpha-\left[{ }^{18} \mathrm{~F}\right]$ fluoro-17 $\beta$-estradiol using a cassette-type $\left[{ }^{18} \mathrm{~F}\right]$ fluorodeoxyglucose synthesizer. Nucl Med Biol, v. 33, p. 281-286, 2006.

16. COUNCIL OF EUROPE. European pharmacopoeia. $7^{\text {th }}$ ed., v. 1. Strasbourg, France: Council of Europe, 2016.

17. DIXIT, M.; SHI, J.; WEI, L.; AFARI, G.; BHATTACHARYYA, S. Synthesis of ClinicalGrade $\left[{ }^{18} \mathrm{~F}\right]$-Fluoroestradiol as a Surrogate PET Biomarker for the Evaluation of Estrogen ReceptorTargeting Therapeutic Drug. Int J Mol Imaging, v. 2013, article ID 278607, 2013. 